\title{
Crayfish plague epizootics in Germany-classification of two German isolates of the crayfish plague fungus Aphanomyces astaci by random amplification of polymorphic DNA
}

\author{
Birgit Oidtmann $^{1, *}$, Lage Cerenius ${ }^{2}$, Ines Schmid ${ }^{1}$, Rudolf Hoffmann ${ }^{1}$, Kenneth Söderhäll ${ }^{2}$ \\ ${ }^{1}$ Institute of Zoology, Fish Biology and Fish Diseases, University of Munich, Kaulbachstr. 37, D-80539 Munich, Germany \\ ${ }^{2}$ Division of Physiological Mycology, University of Uppsala, Villavägen 6, S-752 36 Uppsala, Sweden
}

\begin{abstract}
Following 2 outbreaks of crayfish plague in southern Germany, the causative agent, the oomycete fungus Aphanomyces astaci, was isolated from the diseased Astacus astacus. The identity of the 2 strains was confirmed using established techniques, such as physiology, spore production and the fact that the isolated strains were highly virulent for $A$, astacus in infection experiments. The relationship between these German strains and other $A$ astaci strains was investigated using randomly amplified polymorphic DNA-polymerase chain reaction (RA.PD-PCR). The German strains were found to be closely related to a strain that had been isolated from Pacifastacus leniusculus from Lake Tahoe, USA.
\end{abstract}

KEY WORDS: Crayfish - Aphanomyces astaci RAPD-PCR

The crayfish plague fungus Aphanomyces astaci Schikora (a member of the Saprolegniales), still constitutes a threat to natural populations of European freshwater crayfish species. The cultivation of farmed European crayfish species is at risk from disease unless a farm has its own safe water supply, e.g. spring water. Failing this, the stock is constantly threatened by upstream contamination due to the illegal release of nonnative disease-carrying crayfish or fishing equipment.

The crayfish plague fungus was introduced into Europe following the introduction of North American crayfish (Söderhäll \& Cerenius 1992). North American crayfish species have a low susceptibility for the disease and may carry the fungus in their cuticle over long periods of time as a benign infection, but can die of plague if the individuals are stressed (Söderhäll \& Cerenius 1992). In contrast, European species are highly vulnerable to the disease and regularly suc-

•E-mail: b.oidtmann@zoofisch.vetmed.uni-muenchen.de cumb to infection. During the past century, the distribution of non-native crayfish species has dramatically increased due to stocking activities, the natural spread of stocked populations, and the release of exotic crayfish by private aquarist or pond owners. In areas, where American species have been introduced, mass mortalities of European crayfish have frequently been documented (Alderman 1996).

Mass mortalities of Astacus astacus were observed in 1996 in 3 independent sites in southern Germany separated by at least $80 \mathrm{~km}$. In 2 of the outbreaks diseased crayfish were collected for further investigation. Previous occurrences of mass mortality or disappearance of native crayfish stocks in southern Germany have also been observed (E. Bohl pers. comm.) and the course of disease in these cases, i.e. the duration of mortality and total losses, strongly suggests that crayfish plague was involved. The distribution of crayfish in Bavaria is well documented as a result of stocking surveys (Bohl 1989)

Molecular techniques allow the determination of the degree of relatedness of organisms belonging to one species. Huang et al. (1994) and Dieguez-Uribeondo et al. (1995) applied arbitrary primers and the polymerase chain reaction (PCR) technique to study the genetic variation between different strains of Aphanomyces astaci. These studies allowed the assignment of 4 groups: Group A comprises strains that were isolated from Astacus astacus and also 1 strain from Astacus leptodactylus; these strains are proposed to have been in Europe for a long period of time. Group B includes isolates from both $A$. astacus in Sweden and Pacifastacus leniusculus from Lake Tahoe, USA. In this case, imported $P$. leniusculus probably served as a vector and infected native $A$. astacus. Group $C$ consists of a 
single strain isolated from $P$. leniusculus originating from Pitt Lake, Canada. Group $D$ also currently has only 1 member: a strain isolated from Procambarus clarkii in Spain. The aim of the present study was to investigate whether the German strains could be assigned to 1 of these 4 groups.

Materials and methods. Fungi: German strains $M 96 / 1$ and $M 96 / 2$ : Two strains of Aphanomyces astaci, designated M96/1 and $M 96 / 2$, were isolated following natural outbreaks of crayfish plague on Astacus astacus in southern Germany in spring 1996.

The first isolate, M96/1, originated from Astacus astacus from a pond hatchery fed by a tributary of the river Ammer. No exotic crayfish had been transferred to the farm for the previous $10 \mathrm{yr}$. Seventy diseased $A$. astacus 7.5 to $10.5 \mathrm{~cm}$ in length, weighing 10 to $20 \mathrm{~g}$, were collected from this site.

The second isolate, $M 96 / 2$, originated from Astacus astacus from a private pond hatchery close to the river Kammel. The hatchery has a spring water supply. Only 3 specimens $(8$ to $11 \mathrm{~cm}$ long, weighing 9 to $30 \mathrm{~g})$ were recovered following an outbreak with associated mass mortality.

Both isolation and identification (including zoospore production) of the German strains as Aphanomyces astaci were undertaken using the method of Cerenius et al. (1988). Morphological assignation of the fungi was performed as described by Diéguez-Uribeondo et al. (1995).

Aphanomyces astaci strains for comparative study: The strains chosen for comparison with the German isolates were strain $L 1$, isolated in 1962 from an outbreak of crayfish plague in Astacus astacus in Sweden, and strain $\mathrm{Pl}$, isolated from Pacifastacus leniusculus from Lake Tahoe, USA, in 1970. Strain L1 represents an Aphanomyces astaci strain which has probably been present in Sweden for a long time, whereas strain $\mathrm{Pl}$ may be typical of Aphanomyces astaci strains that have been introduced into Europe only recently (see also Table 1).

Challenge experiments: Challenge experiments were performed with German isolates $M 96 / 1$ and $M 96 / 2$ using the method of Rantamäki et al. (1992): Clean Astacus astacus were kept in $50 \mathrm{I}$ aquaria in aerated tap water at $17^{\circ} \mathrm{C}$ for at least 8 wk before the experiment. One week before the infection experiment the cray-
Table 1. Aphanomyces astaci genotype groups as identified from randomly amplified polymorphic DNA-polymerase chain reaction (RAPD-PCR) data by Huang et al. (1994), Vennerström et al. (1998), Dieguez-Uribeondo et al. (1995), Dieguez-Uribeondo (pers. comm.) and this paper. Year: year of isolation

\begin{tabular}{|llll|}
\hline Isolate & Year & Country & Host \\
\hline Astacus strain (Group A) & & \\
J1 & 1962 & Sweden & Noble crayfish \\
L1 & 1962 & Sweden & Noble crayfish \\
Uv & 1970 & Sweden & Noble crayfish \\
VI & 1970 & Sweden & Noble crayfish \\
Sv & 1970 & Sweden & Noble crayfish \\
Da & 1973 & Sweden & Noble crayfish \\
Ra & 1973 & Sweden & Noble crayfish \\
Vå & 1973 & Sweden & Noble crayfish \\
Al & 1988 & Turkey & Narrow-clawed crayfish \\
K136 & 1995 & Finland & Noble crayfish \\
Pacifastacus & strain I (Group B) & & \\
Pl & 1970 & USA & Signal crayfish \\
Si & 1970 & Sweden & Noble crayfish \\
Ti & 1970 & Sweden & Noble crayfish \\
SA & 1971 & Sweden & Signal crayfish \\
Yx & 1973 & Sweden & Noble crayfish \\
Hö & 1974 & Sweden & Noble crayfish \\
K121 & 1995 & Finland & Noble crayfish \\
FDL457 & 1990 & England & White-clawed crayfish \\
FDL458 & 1990 & England & White-clawed crayfish \\
M96/1 & 1996 & Germany & Noble crayfish \\
M96/2 & 1996 & Germany & Noble crayfish \\
& 1997 & Spain & White-clawed crayfish \\
Pacifastacus strain II (Group C) & Sweden & Signal crayfish (from \\
Kv & 1978 & & Pitt Lake in Canada) \\
& & & \\
Procambarus strain (Group D) & Spain & Red swamp crayfish \\
Pc & 1992 & & \\
& & &
\end{tabular}

fish were transferred into 101 aquaria, containing aerated tap water and brick tubes that allowed each crayfish to hide. Only intermolt crayfish were used. During the infection trial, the crayfish were not fed. Individuals that died during the experiments were examined for the presence of Aphanomyces astaci hyphae in the cuticle. Detailed experimental conditions are shown in Table 2.

DNA preparation: Mycelia were produced by cultivating the fungus at $20^{\circ} \mathrm{C}$ in $200 \mathrm{ml} \mathrm{PG1} \mathrm{medium,} \mathrm{as}$

Table 2. Infection trial parameters

\begin{tabular}{|c|c|c|c|}
\hline \multicolumn{4}{|l|}{ Parameter } \\
\hline Species & \multicolumn{3}{|c|}{ Astacus astacus } \\
\hline No. of ind. in experiment & \multicolumn{2}{|c|}{10} & \\
\hline Water volume & \multicolumn{2}{|c|}{101} & \\
\hline Temperature & \multicolumn{2}{|c|}{$17^{\circ} \mathrm{C}$} & \\
\hline \multirow[t]{2}{*}{ Size of ind. } & \multicolumn{2}{|c|}{$2.0-5.0 \mathrm{~cm}$} & \\
\hline & Strain M96/1 & Strain M96/2 & Control \\
\hline Spores $\mathrm{ml}^{-1}$ at start of experiment & 5150 & 1700 & - \\
\hline Motility of spores added & $30 \%$ & $0 \%$ & - \\
\hline
\end{tabular}


Table 3. Sequence of primers used

\begin{tabular}{|ll|}
\hline Primer & Sequence \\
\hline B01 & 5'-GTTTCGCTCC \\
B03 & 5'-CATCCCCCTG \\
\hline
\end{tabular}

described by Söderhäll \& Cerenius (1987). DNA was extracted using a Nucleon II kit following the manufacturer's (Scotlab) instructions for preparation of DNA from mycelial fungi.

Randomly amplified polymorphic DNA (RAPD)PCR: The RAPD-PCR was performed as described by Huang et al. (1994) with slight modifications. The RAPD reactions were carried out in a $50 \mu$ l volume containing $1.6 \mathrm{ng}$ fungal DNA, $1.5 \mathrm{mM} \mathrm{MgCl}, 5 \mu \mathrm{l} 10-\mathrm{X}$ buffer (Amersham), $200 \mu \mathrm{M}$ of each dNTP (Pharmacia), and 2.5 units of Ampli Taq-polymerase (USB). Reactions were carried out in $0.2 \mathrm{ml}$ test tubes in a programmable heat block (Perkin Elmer 2400 Gene Amp PCR System). The reaction conditions were identical to those described by Huang et al. (1994) with the exception that the samples were first heated at $94^{\circ} \mathrm{C}$ for $5 \mathrm{~min}$ followed by $2 \mathrm{~min}$ at $80^{\circ} \mathrm{C}$. The sequences of the primers are shown in Table 3.

Results and discussion. Following 2 outbreaks of crayfish plague in Astacus astacus crayfish in southern Germany, Aphanomyces-like strains were recovered from diseased $A$. astacus.

The German strains were morphologically similar to a range of other Aphanomyces astaci strains. As is the case for all other $A$. astaci strains, the formation of sexual structures could not be induced by growth on suitable indicator media such as corn meal agar. The diameter of hyphae was 3.0 to $12.7 \mu \mathrm{m}$. Spore production was observed $10 \mathrm{~h}$ after transfer of mycelia from PG1 medium into sterilized river water at $16^{\circ} \mathrm{C}$. As morphology alone is insufficient for the identification of A. astaci, infection experiments were performed using healthy Astacus astacus. After addition of zoospores, the first crayfish died on Day 2 of the experiment (both strain M96/1 and M96/2). All A. astacus infected with strain M96/1 died by Day 8 of the experiment, and all $A$. astacus, infected with $\mathrm{M} 96 / 2$ were dead by Day 4 . In the control group all crayfish were still alive at Week 4. All deceased crayfish exhibited a dense net of fungal hyphae within their abdominal cuticle. Clinical symptoms exhibited were lack of coordination, tendency of crayfish to lie on their dorsal surfaces, scratching and loss of pereopods.

The RAPD-PCR results (Fig. 1) confirm the identification of the isolated fungus as Aphanomyces astaci. Bands similar to those seen in A. astaci strain Pl and very different to those of strain L1 are present. Thus, the German strains can be assigned to Group B, as described by Diéguez-Uribeondo et al. (1995). This group contains isolates from Pacifastacus leniusculus originating from California, as well as isolates from Astacus astacus which have been infected as a result of proximity to $P$. leniusculus. This supports the hypothesis that the German outbreaks were caused by a recent introduction of Aphanomyces astaci. The most likely route for $A$. astaci to Germany from the U.S. in recent years was probably via Sweden, vectored by $P$. leniusculus.

The hatchery where strain M96/1 was isolated had not had related disease problems for a period of at least $16 y r$ and thus may be regarded as free of crayfish plague during that time. Wild stocks of Astacus astacus and Austropotamobius torrentium were observed in the upstream drain system prior to the epizootic and are currently still present. During the period 1984 to 1989, crayfish stock surveys revealed no occurrence of foreign crayfish species within a $50 \mathrm{~km}$ radius of the site (Bohl 1989). Since 1989 regular test fishing for crayfish has been performed in the area around the crayfish farm, the number of sites sampled varying between 5 and 10 every year. No non-native species have ever been detected.

The private pond hatchery where strain M96/2 was isolated has its own spring water supply. Aphanomyces astacus were introduced into the hatchery in autumn 1995, but losses did not occur before the spring of 1996.

The method of infection is unknown in both cases. The distance between the 2 sites is approximately

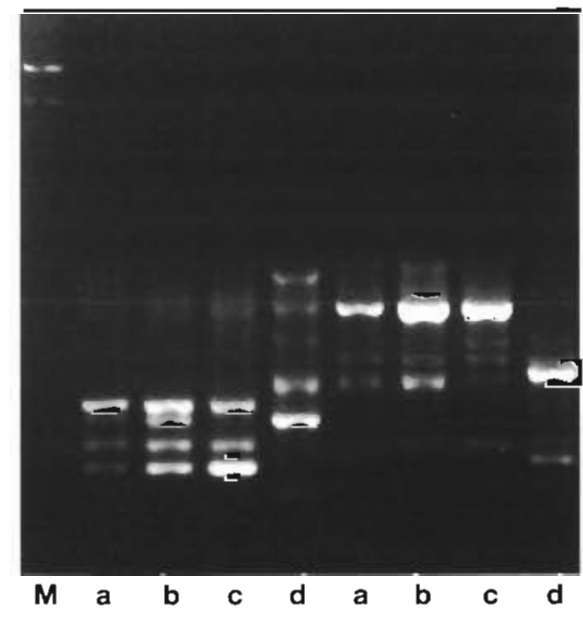

Fig. 1. Aphanomyces astaci. RAPD analysis of 2 German isolates, strain $\mathrm{Pl}$, isolated from the introduced North American crayfish Pacifastacus leniusculus, and strain L1, isolated from Astacus astacus crayfish. Left to right: $\lambda$ Hind III size standards (M), and strains Pl (a), M96/1 (b), M96/2 (c) and L1 (d) amplified with primer $\mathrm{BO} 1$ followed by the same strains amplified with primer $\mathrm{BO}$. Note that both German strains are almost identical to strain Pl 
$80 \mathrm{~km}$. As RAPD-PCR revealed only small differences in the DNA pattern between the German strains, it is likely that the strains came from a related source; however, a direct connection between these epizootics is improbable because the DNA patterns are not exactly the same. In both cases introduction of exogenous crayfish into the hatchery may be excluded as a possible source of the plague fungus. In the vicinity of the M96/2 farm, stocks of Procambarus clarkii were observed in a gravel pond at a distance of about $15 \mathrm{~km}$. Whether these crayfish were the source of the plague is unclear. RAPD-PCR indicates that the fungus is closely related to a strain that was originally isolated from Pacifastacus leniusculus, suggesting that the source may have been a signal crayfish. On the other hand, it cannot be ruled out that an American crayfish species can be infected with an Aphanomyces strain from another species. Thus, even if the German strains are assigned to Group B (Pacifastacus strain I), this does not necessarily imply that a signal crayfish was the disease transmitting agent. The results of this study suggest that a more detailed study of American crayfish populations in Europe is warranted in order to determine the extent and source of the fungal strains present.

In Germany, release of exotic crayfish species into open waters is widely prohibited by fisheries and environmental legislation. However, the rearing of alien species in closed ponds or aquaria is permitted. Illegal release of an alien crayfish species is a probable explanation for the epizootics reported in this paper. Nonetheless, the possibility of transmission by waterfowl, mammalian crayfish predators, fish, or humans cannot be ruled out. These outbreaks of crayfish plague highlight the need for further studies to investigate the possible mode of transmission of Aphanomyces astaci.

Editorial responsibility: Larry Vaughan, Arlington, Massachusetts, USA
Acknowledgements. This study was supported by the European Commission (FAIR PL-97-3660), the Swedish Council for Forestry and Agricultural Research, and the fishing license fee of the Land Baden-Württemberg, Germany. Ragnar Ajaxon is thanked for excellent technical assistance

\section{LITERATURE CITED}

Alderman DJ (1996) Geographical spread of bacterial and fungal diseases of crustaceans. Rev Sci Tech Off Int Epizoot 15(2):603-632

Bohl E (1989) Ökologische Untersuchungen zur Entwicklung von Zielvorstellungen des Gewässerschutzes: Untersuchungen an Flußkrebsbeständen. Schriftenreihe der Bayerischen Landesanstalt für Wasserforschung, Wielenbach

Cerenius L, Söderhäll K, Persson M, Ajaxon R (1988) The crayfish plague fungus Aphanomyces astaci-diagnosis, isolation and pathobiology. Freshw Crayfish 7:131-144

Diéguez-Uribeondo J, Huang TS, Cerenius L, Söderhäll K (1995) Physiological adaptation of an Aphanomyces astaci strain isolated from the freshwater crayfish Procambarus clarkii. Mycol Res 99:574-578

Huang TS, Cerenius L, Söderhäll K (1994) Analysis of genetic diversity in crayfish plague fungus, Aphanomyces astaci, by random amplification of polymorphic DNA. Aquaculture 126:1-10

Rantamäki J, Cerenius L, Söderhäll K (1992) Prevention of transmission of the crayfish plague fungus (Aphanomyces astaci) to the freshwater crayfish Astacus astacus by treatment with $\mathrm{MgCl}_{2}$. Aquaculture 104:11-18

Söderhäll K, Cerenius L (1987) Controlled growth and development in filamentous oomycetes with emphasis on Aphanomyces astaci. In: Fuller MS, Jaworski A (eds) Zoosporic fungi in teaching and research. Palfrey contributions in botany, no 3. Southeastern Publishing Corp., Athens, GA, p 264-267

Söderhäll K, Cerenius L (1992) Crustacean immunity. Annu Rev Fish Dis 2:3-23

Vennerström P, Söderhäll K, Cerenius L (1998) The origin of two crayfish plague (Aphanomyces astaci) epizootics in Finland on noble crayfish, Astacus astacus. Annu Zool Fennici 35:43-46

Submitted: April 21, 1998; Accepted: December 30, 1998 Proofs received from author(s): February 10, 1999 